\title{
“Didong” Art as Health Promotion to Improve Natural Disaster Awareness
}

\author{
${ }^{1}$ Nur Asiah, ${ }^{1}$ Ryan Indrawan, ${ }^{2}$ Firman Parlindungan \\ ${ }^{1}$ Akademi Keperawatan Teungku Fakinah, Banda Aceh, Indonesia \\ ${ }^{2}$ Curriculum and Language Development Center, Universitas Teuku Umar, Aceh, Indonesia \\ Coresponding author: Nur Asiah, e-mail: nurasiahsetiawwan1976@gmail.com \\ Co-author : RI: ryanindrawan@akpertgkfakinah.ac.id, FP : firman@utu.ac.id
}

Submitted: 16/09/2020 Revised: 02/10/2020 Accepted: 19/10/2020 Published online: 21/10/2020

doi: https://doi.org/10.35308/j-kesmas.v7i2.2728 How to cite this article: Asiah, N., Indrawan, R., \& Parlindungan, F. (2020).

"Didong" Art as Health Promotion to Improve Natural Disaster Awareness. J-Kesmas: Jurnal Fakultas Kesehatan Masyarakat (The Indonesian Journal of Public Health), 7(2), 111-116.

\begin{abstract}
Didong is one of the cultural arts originating from the Gayo tribe of Bener Meriah, Takengon and Gayo Lues Regencies in Aceh Province, Indonesia. Furthermore, it is an art that combines movement, vocals and artistic literature to educate the public about government programs, such as health-care sector in the context of health promotion. The Bener Meriah regency experienced an earthquake in 2013, which result in the death of 14 people and 100 were injured. Therefore, this study aims to determine the didong art as a medium for health promotion, and the sample used were purposive sampling, which include the recitation group of 69 people. Also, a pre-experimental design with one shot case study was used. Furthermore, data was collection techniques include questionnaires, observation and interviews, and it was analyzed using percentage descriptive method to describe all varriables The community watched the didong art performance via video for 20 minutes, and subsequently an assessment was performed on the community. Based on the results, $85 \%$ of community groups stated that the didong art was used as a tool in health promotion in relation to the effect of natural disasters on public health. The art's unique local wisdom makes it easier for the community to understand the contents of didong art poetry, which contains messages regarding the impact of natural disaster in public health. In addition, the poetry was translated into Indonesia for easy understanding by people other than the Gayo tribe. Therefore, in order to determine the level of effectiveness in the use of didong art as promotion medium for public awareness about the effect of natural disaster, this research needs to be continued.
\end{abstract}

Keywords: Didong Art, Health Promotion Media, Natural Disasters.

\section{Introduction}

Indonesia is one of country that is really potential to have some natural disasters. In every natural disaster, there is always some disadvantages for human's life and it cannot be predicted. Based on the consideration of the impacts of the natural disaster on human's life, there should be some effort especially from the government as it is their responsibility to manage the continuity and the persistence of life. Based on the rule number 24 year 2007, it is stated that natural disaster is a disaster caused by earthquake, tsunami, eruption, dryness, hurricane, and erosion.

For the people in Aceh province, after the disaster of tsunami on 26th December 2004 with around 115.000 victims, it gave some important experience and lesson for many Indonesian and especially for people in Aceh.

The experience of natural disaster happened in the past time could be an effort to the prevention and handling the impact of natural disaster for their life. One kind of impacts is the damage of other health facilities.

The impact that could be directly felt by the people for their health is the physical injury for people who experience the disaster. Another impact is the increasement of some contaminating illnesses and the disturbance of nutrient fulfillment which is really crucial for the certain age like infants, pregnant women, and some old people.

The people as the object who experience the impact of some particular disasters need to get involved in the effort of the prevention and handling the natural disaster and inform them about the natural disaster to give knowledge through some interesting media.

To conduct the process of delivering health information, there should be some health promotion during the disaster itself. This is really helpful to prevent and to increase people's health. (Trisnowati, 2017)

The consideration of the appropriate media as the aid to deliver information in promoting health influences the people to know and to have the ability 
to implement information from the messages they get. For the Gayo community in Bener Meriah province, didong art is the media used in various shows of social activities.

Based on the interview result with the headman of the village which is called "Reje" in Gayo language, it shows that people in Blang Rongka village, Timang Gajah, Bener Meriah regency are very enthusiastic to see the show of didong art in every social activity such as wedding ceremony, Islamic celebration, and many more. Thus, the researcher was interested to analyze the didong art as the aid for health promotion about the impact of natural disaster on human's health.

\section{Materials and Methods}

The research method used on this study is preexperimental design with one shot case study. This means giving the treatment for the people who watch the show of didong art. On this study, the show of didong art is through video watched by the respondents and completed by the lyrics with full of messages about health and the impact of natural disaster. After that, the researcher evaluated the respondents by using questionnaire and interview. The population of the research was the people in Blang Rongka village, Timang Gajah, Benar Meriah regency. The sample of the research is the group of majelis taklim chosen by using purposive sampling. They are from Gayo community with 69 people. This research was conducted from July to August 2020. The instruments of the research were the videos of didong art and questionnaire papers with some questions to obtain the data about the message of the lyric in didong art. The method of analyzing the data was descriptive analysis using percentage to describe the whole variables.

\section{Results and Discussion}

\section{The Description of Didong Art}

Based on the result of the didong art show through video which was played for 20 minutes in Blang Rongka village, there were a "ceh" and some groups with 5 people called as "penunung ." The show was started with the same body movement along with the applause. The palm of the left hand went upwards with the small pillow around $15 \times 15$ $\mathrm{cm}$. The palm of the right hand slapped the pillow based on the rhythm sung by the ceh. A member between penunung gave the command to head the harmony of the applause from the escorts. The applause from the escorts would continuously change based on the rhyme of the song.

Ceh sang the rhyme followed by the applause from the escorts on the pillows with the low claps to make the message clear and people could hear it. On the refrain part, ceh with the escorts made and gave harmonious applause between the rhyme and body movement. This part is repeated 3 times. After that, ceh could sing the next rhyme until the ceh finished the whole song about the impact of natural disaster on human's health.

Table 1. The Description of the Respondents' Characters

\begin{tabular}{lcc}
\hline \multicolumn{1}{c}{ Gender } & Frequently & Percentage $\mathbf{( \% )}$ \\
\hline Male & 20 & 29 \\
Female & 49 & 71 \\
Total & 69 & 100 \\
\hline Age & & \\
\hline 20-30 years old & 9 & 13 \\
31-40 years old & 21 & 31 \\
41-50 years old & 26 & 38 \\
51-60 years old & 12 & 17 \\
Over 60 years old & 1 & 1 \\
Total & 69 & 100 \\
\hline Occupation & & \\
\hline Farmer & 55 & 80 \\
Entrepreuneur & 4 & 6 \\
Housewife & 4 & 6 \\
Government Empliyee & 6 & 8 \\
(PNS) & & \\
Total & 69 & 100 \\
\hline Education & & \\
\hline High & 8 & 12 \\
Middle & 47 & 68 \\
Low & 14 & 20 \\
Total & 69 & 100 \\
\hline Experience of Natural & & \\
Disaster & & \\
\hline Experienced & 69 & \\
No Experienced & 69 & \\
Total & & \\
\hline
\end{tabular}

From the table 1, there are 69 respondents who $100 \%$ experienced the natural disaster. This data shows that those people meet the characters or criteria to have information from various media about health. This is because there are so many people who had experienced the disaster. From the interview, 19 respondents stated, "In our living areas, it always happens the natural disaster".

The Blang Rongka village is one of area with so many hills and mountains and it has high potency of natural disaster such as flood, erosion, and earthquake. The people need to increase the knowledge of how they have self-prevention to the natural disaster which might happen suddenly. The area with the high potency of natural disaster should be able to prevent and to decrease the impact of the 
natural disaster itself for their life and especially for their health. According to Notoatmojo (2012), experience is the best teacher which can be a resource of knowledge. Based on this statement, it is important to have self-prevention of the natural disaster as the effort to handle the following disaster. As the effort consideration, the interesting media is needed to promote the health by using the local culture.

Table 2. Didong Art as the Health Promotion Mediaof the Natural Disaster Impact on Health.

\begin{tabular}{lcc}
\hline $\begin{array}{c}\text { Health Promotion } \\
\text { Media }\end{array}$ & Frequency & $\begin{array}{c}\text { Percentage } \\
(\boldsymbol{\%})\end{array}$ \\
\hline Yes & 52 & 85,4 \\
No & 17 & 28,6 \\
Total & 69 & 100 \\
\hline
\end{tabular}

Based on table 2, 85,4\% respondents shows that didong art could be taken as a media for health promotion because this art uses the local language and melodious voice of ceh makes the whole respondents interested to listen and follow every rhyme.

Respondent 5 says:

"When they were children, they always warched didong art abd it was always attende by so many people."

According to Arlin Adam, Erwin Wintoni (2016), the appropriate choice of media for health promotion will ease them to deliver information of some objectives of the activity. To change the people's attitude in accepting information, it needs an interesting media to convey the appropriate information with social culture approach.

Didong art as the Gayo art still exists and it represents the Gayo people from their life which is expressed through the art. So that, it can be used not only as the entertainment media but also as the promotion media for health.

The choice and consideration of the interesting media for health promotion will influence the objective achievement of the program such as the program to change the knowledge and their attitude. Natural disasters may happen everytime and the impact on health could also happen to everyone, so that it is important to deliver information through the media that is close to their social life. Through didong art, Gayo people will accept the information well and it is also as an effective media that could influence, educate, persuade, as well as entrtain the people.

Table 3. The Distribution of Respondents' Frequency Based on Didong Art as the Health Information Media Kesehatan about the Impact of Natural Disaster on People
Health in Timang Gajah Bener Meriah Regency 2020.

\begin{tabular}{lcc}
\hline $\begin{array}{c}\text { Health Promotion } \\
\text { Media }\end{array}$ & Frequency & $\begin{array}{c}\text { Percentage } \\
(\boldsymbol{\%})\end{array}$ \\
\hline Yes & 55 & 79,7 \\
No & 14 & 20,3 \\
Total & 69 & 100 \\
\hline
\end{tabular}

Based on table 3, the percentage of $79,7 \%$ respondents agreed that didong art could be used as the information media about the impact of the natural disaster on health and based on the result of interview, 36 respondents said that:

"By watching didong show, we could see, listen, and also follow the lyric sung by the didong ceh and also understand the message behind it."

According to Trisnowati H (2017), the activity of health promotion about the impact of natural disaster by using an interesting media is very useful for people's health who experience the natural disaster. It would be the attraction for the people to know the information behind it.

Didong art is the collaboration between music, movement, and dance and it becomes an interesting media for the people to follow and enjoy the lyric sung by the ceh using sense of sight and hearing in accepting the message and they would also get more knowledge about it.

Table 4. The Distribution of Respondents' Frequency Based on Didong Art as an Educating Media for Health Promotion about the Impact of Natural Disaster on Human's Health in Timang Gajah, Bener Meriah Regency 2020.

\begin{tabular}{lcc}
\hline $\begin{array}{c}\text { Health Promotion } \\
\text { Media }\end{array}$ & Frequency & $\begin{array}{c}\text { Percentage } \\
(\boldsymbol{\%})\end{array}$ \\
\hline Yes & 56 & 81,2 \\
No & 13 & 18,8 \\
Total & 69 & 100 \\
\hline
\end{tabular}

Based on table 4, it shows that $81,2 \%$ said that didong art could be used as an educating media and based on the result of interview, 15 respondents said that.

"Through didong art, I am able to know that if a natural disaster happens, we should keep our health."

Didong art is a universal art used in various activities like health promotion (Winarno,Sumarni 2005). From the results of educational information, it is expected that a person's behavior changes for the better by implementing the results of the information received. The didong art can be used widely to convey information in the form of knowledge through poetry and lyric which contain the impact of 
disasters on health, so that people are motivated to apply the information received.

Table 5. Distribusi The Distribution of Respondents' Frequency based on Didong Art as an Entertaining Media for Health Promotion about the Impact of Natural Disasters on Health in Timang Gajah, Bener Meriah Regency 2020.

\begin{tabular}{lcc}
\hline $\begin{array}{c}\text { Health Promotion } \\
\text { Media }\end{array}$ & Frequency & $\begin{array}{c}\text { Percentage } \\
(\boldsymbol{\%})\end{array}$ \\
\hline Yes & 45 & 65,5 \\
No & 24 & 34,8 \\
Total & 69 & 100 \\
\hline
\end{tabular}

Based on table 5 , the results of the study states that $65.2 \%$ of art was performed as an entertaining media. Didong art grows and develops in the social life of Gayo community and it has been used as a means of entertainment to create a sense of joy in social life and used in social activities such as a wedding party. Didong art is interpreted as a manifestation of a sense of joy. This is in accordance with what was conveyed by respondents 23 :

"Before the Covid 19 pandemic, art performances were usually held in the villages to celebrate Indonesia's Independence Day every 17 August"

Didong as an art and culture is a part of people's life to express sadness, joy, and it is produced from the expression of a poets which contains a situation that he has experienced. After the occurrence of a natural disaster, the impact for the community is not only on physical health problems but also on psychological issues. In natural disasters experienced by the community, psychological health management is needed by providing a sense of security and comfort for victims of natural disasters to overcome trauma due to natural disasters. In overcoming trauma, an effective health promotion media is needed to restore the sense of joy and hope of the people who experience them. The art of didong is one of the media that can be used to convey entertaining messages.

This is in accordance with the opinion of Afriandi, P (2017) who stated that the lyrics are an inspirer for the community with a touch of soothing feelings because the chanting of the lyrics full of the meaning of submitting oneself to the Almighty will be an entertainer in times of disaster and it is accordance with one of the functions of didong art which is to express feelings.

Table 6. Distribution of Respondents' Frequency based on Didong Art as Influencing Media for Health Promotion about the Impact of Natural Disasters on Health in Timang Gajah, Bener Meriah Regency 2020.

\begin{tabular}{lcc}
\hline Influencing Media & Frequency & Percentage (\%) \\
\hline Yes & 42 & 60,9 \\
No & 27 & 39,1 \\
Total & 69 & 100 \\
\hline
\end{tabular}

Based on table 6 , it was found that $60.9 \%$ of the results stated that the art of didong as a health promotion media affects the community. From the results of the interview with respondent number 10 , the respondent stated that, "I never feel bored to watch the didong art performance".

The didong art as a health promotion media grows and develops in the life of Gayo community. It can change people's knowledge and also behavior in handling health problems. This is in accordance with the opinion of Elliyil Akbar (2018) who stated that the value of didong poetry contains the elements of beauty and religion which come from local wisdom. It makes didong poetry as a health message that is conveyed to the public make people aware of the behavior of a clean and healthy life after a natural disaster. Thus, didong art can be used to raise public awareness of guarding behavior and reduce the risk of natural disasters for public health and to stimulate people's thoughts, feelings and concerns about health.

\section{Conclusion}

1. Didong art as a health promotion media about the impact of natural disasters on people's health in Blang Rongka Village, Timang Gajah, and Central Aceh Regency shows that 59.4\% respondents said that didong art can be used as a health promotion media.

2. The art of didong as an information media for health promotion about the impact of natural disasters on the community in Blang Rongka village, Timang Gajah, Bener Meriah Regency shows that $79.9 \%$ agreed that didong art could be as a media of information for good health promotion in conveying health messages to the Gayo community.

3. Didong art as an entertaining media for health promotion about the impact of natural disasters in Blang Rongka village, Timang Gajah, Bener Meriah Regency, stated that $65.2 \%$ agreed that didong art was an entertaining media.

4. Didong art as an influencing media in Rongka Village, Timang Gajah, Bener Meriah Regency, states that $60.9 \%$ agreed that didong art can be used as a health promotion media that can 
influence the community about the impact of natural disasters on health.

\section{Acknowledgement}

This research was carried out well because of help from other parties.

\section{Author Contribution and Competing Interest}

All of the authors contributed in collecting and analyzing the data, including preparing the manuscript. The author assures thet there is no conflict of interest in the activities and preparation of this report.

\section{Publisher's Note}

J-Kesmas: Jurnal Fakultas Kesehatan Masyarakat (Indonesia Journal of Public Health) remains neutral with regard to jurisdictional claims in published institutional affiliation.

\section{References}

Afriandi, Putra (2017). Fungsi Dan Multikulturalisme Dalam Seni Didong Pada Masyarakat Gayo Kabupaten Aceh Tengah. Jurnal Imaji, 15(2), 207-218.

Arlin Adam, Erwin Wintoni. (2016). Pengaruh Media Promosi Kesehatan Terhadap Perilaku Kesehatan Pada Remaja Kelas XI di SMA Negeri I Pangkejene. Jurnal Media komunitas Kesehatan, 8(1), 1-9.

Ayub Esperanza, Samuel M, Simanjuntak. (2020). Pengetahuan tentang kesiapsiangaan Bencana Melalui Promosi dan Pelatihan Siaga Gempa Bumi. Jurnal Media Karya Kesehatan, I(1), 114.

Ayu Nurul Chatimah. (2019). Pengaruh Pengetahuan dan Sikap Masyarakat Terhadap Kesiapsiagaan Mengahadapi Bencana Longsor di Pasir Jaya, Bogor. Jurnal Manajemen Bencana, 5(2), 57-72.

Cahyadi Adiwijaya. (2017). Pengaruh pengetahuan kebencanaan dan sikap masyarakat terhadap kesiapsiagaan menghadapi bencana tanah longsor (studi di keluruhan lawanggitung kecamatan bogor selatan Kota Bogor ). Jurnal Manajemen Bencana, 3(2), 81-99.

Effendi, Onong Uchjana. (2003). Ilmu, Teori dan Filsafat Komunikasi. Bandung: Citra Aditya Bakti.

Eliyyil Akbar. (2015), Pendidikan Islami Dalam Nila-Nilai Kearifan Lokal Didong, Jurnal A-
Tahrir, 15(1), 43-65.

Evi Tunjung Fitriani, Febriana In Patmiati. (2019). Pengaruh Pendidikan Kesehatan Tentang Kesiapsiagaan masayarakat Terhadap Sikap Masayarakat Dalam Mengatasai Masalah Kesehatan Akibat Bencana Tanah Longsor .Jurnal Keperawatan Jiwa, 7(1), 71-78.

Fajar Wulandari. (2018). Pengaruh Media Video Terhadap Kesiapsiagaan Siswa Dalam Menghadapai Bencana GempaBumi di SMA Negeri 1 Gantiwaringin Kabupaten Klaten. Jurnal PIPSI Pendidikan Pengetahuan Sosial Indonesia, 3(2), 18-20.

Hasni Rinolla Hasibuan ( 2013 ). Kesenian Didong Group Bayakku Pada Acara Syukuran Munik $\mathrm{Ni}$ Reje Di Redelong. Tesis Universitas Pendidikan Indonesia.

Trisnowati H. (2017). Promosi Kesehatan Dalam Keadaan Bencana (Studi Kasus Bencana Gunung Merapi di Yogyakarta. Publich Health \& Science Symposium. Conference Paper May 2017.

Khairani, Etty Soesilowati, Thriwaty Arsal. (2017). Kearifan Lokal Masyarakat Etnis Gayo sebagai Destinasi Wisata Budaya di Takengon. Journal of Education Social Studies, 6(3), 99-110.

Muhammad Hadiyanul Haqi, Eka Mishbahatul M.Has, Khoridatul Bahiyah. (2019). Gamabaran status mental (stress,kecemasan dandepresi) Pada korban pasca bencana berdasarkan periode perkembangan (remaja,dewasa dan lansia) di Desa Pendua kabuoaten Lombok utara. Jurnal Keperawatan Jiwa, 1(1), 29-35.

Notoatmojo. S. (2010) Ilmu Perilaku Kesehatan. Jakarta: Rineka Cipta

Notoatmojo. S. (2012). Promosi Kesehatan dan Perilaku Kesehatan. Jakarta: Rineka Cipta.

Rizanda Machmud. (2009). Peran Petugas Kesehatan Dalam Penanggulangan Bencana. Jurnal kesehatan Andalas, 3(1), 28-34.

Rudianto. (2015). Komunikasi Dalam Penanggulangan Bencana. Jurnal Simbolika Research and Learning in communication study, l(1), 51-60.

Susilawati,A.Efendi,f \& Hadisuryatmana S. (2019). Gambaran Kesiepan Tenaga Kesehatan dalam manajemen Bencana di Puskesmas wilayah Rawan Bencana. Indonesian. Jurnal of Community Health Nursing, 4(1), 11-16.

Syaifullah Kholik, Fathurrman, Ida Rahmawati. (2016). Intervensi Media Promosi Kesehatan Melalui Kesenian Banjar Untuk Meningkatkan Kesehatan Ibu Dan Anak Di Kalimatan Selatan. Jurnal Skala Kesehatan, 7(1), 76-82. 
Sugiyono. (2013). Metode Penelitian Pendidikan Pendekatan Kuantitatif kualitatif dan $R \& D$. Bandung: Alfabeta.

Tian Havwina, Enok Maryani, Nandi. (2016). Pengaruh Pengalaman Bencana Terhadap Kesiapsiagaan Peserta Didik Dalam Menghadapi Ancaman Gempa Bumi dan Tsunami (Studi Kasus pada SMA Negeri Siaga Bencana Kota Banda Aceh). Jurnal Pendidikan Geografi, 16(2), 124-131.

Weny Lestari, Suci Wulansari. (2018). Pertunjukn Wayang Interaktif Sebagai Sarana Promosi Kesehatan Remaja tentang Rokok, Narkoba, dan Pergaulan Bebas. Buletin Penelitian Sistem Kesehatan, 21(2), 125-132.

Widayatun, Zainal Fatoni. (2015). Permasalahan kesehatan dalam kondisi bencana: Peran petugas dan partisipasi Masyarakat. Jurnal kependudukan Indonesia LIPI. 8(1), 37-50.

Winarno, Sumarni. (2005) Persepsi Mahasiswa Aceh Gayo di Yogyakarta terhadap "didong" sebagai media promosi pembangunan kesehatan Kabupaten Aceh Tengah. Tesis Ilmu kesehatan Masyarakat Univesitas Gajah Mada.

Win Rudhi Bathin. (2010). Didong dimulai sejak Jaman Reje linge XIII. $\mathrm{http} / /$ keninggayo.wordpress.com. diakses tanggal 19 Mei 2020

Yoga, S. (2013) Didong Media Trasnforamsi Masyarakat Gayo. Listasgayo.com. Diakses tanggal 21 Juli 2020.

Zurryantun Thoyibah. (2019). Gambaran Dampak kecemasan dan gejala psikologis pada anak korban bencana alam gempa di Lombok. Journal of Holistic Nursing, 2(1), 31-38. 